\title{
PERILAKU LGBT DALAM PERSPEKTIF KONSTITUSI NEGARA REPUBLIK INDONESIA DAN PUTUSAN MAHKAMAH KONSTITUSI NOMOR 46/PUU-XIV/2016
}

\author{
Eka NAM Sihombing \\ Fakultas Hukum Univ. Muhammadiyah Sumatera Utara \\ E-mail : ekahombing@gmail.com
}

\begin{abstract}
Abstrak
Pasca putusan Mahkamah Konstitusi (MK) Nomor 46/PUU-XIV/2016, Isu kriminalisasi terhadap perilaku LGBT (Lesbian, Gay, Bisexual, Transexual) dalam peraturan perundang-undangan di Indonesia masih saja menuai silang pendapat. Tulisan ini mencoba untuk mengurai kembali bagaimana sebenarnya perilaku LGBT dan/atau perkawinan sejenis dari perspektif konstitusi di Indonesia, dan bagaimana pula kaitannya antara perilaku LGBT dan/atau perkawinan sejenis dikaitkan dengan putusan MK Nomor 46/PUU-XIV/2016. Hasil penelitian menunjukkan bahwa UUDNRI Tahun 1945 tidak memberikan ruang terhadap perilaku LGBT dan/atau perkawinan sejenis bukan berarti mengabaikan hak-hak asasi kaum LGBT sebagai warga negara yang diakui dalam konstitusi maupun peraturan perundang-undangan lainnya. Pada prinsipnya putusan Mahkamah Konstitusi Nomor 46/PUU-XIV/2016, bukan sebagai dasar dalam melegalkan perilaku LGBT dan/atau perkawinan sejenis di Indonesia. Putusan ini hanya menyatakan bahwa kewenangan untuk memberikan norma baru sesuai dengan pendapat mayoritas hakim Mahkamah Konstitusi adalah open legal policy dari pembentuk undang-undang.
\end{abstract}

Kata Kunci : Perilaku LGBT, Putusan Mahkamah Konstitusi.

\section{PENDAHULUAN}

Pasca putusan Mahkamah Konstitusi (MK) Nomor 46/PUU-XIV/2016, Isu kriminalisasi terhadap perilaku LGBT (Lesbian, Gay, Bisexual, Transexual) dalam peraturan perundang-undangan di Indonesia masih saja menuai silang pendapat. Beberapa pihak menganggap bahwa putusan tersebut merupakan kemenangan kaum LGBT, karena MK menolak untuk melakukan perluasan makna perzinahan, perbuatan cabul dan perkosaan yang diatur dalam Pasal 284 (perzinahan), Pasal 285 (perkosaan) dan Pasal 292 (perbuatan cabul) KUHP sebagaimana yang dimohonkan oleh para pemohon pengujian konstitusionalitas ketentuan dimaksud. Namun tidak sedikit yang berpandangan bahwa putusan MK tersebut bukan merupakan wujud affirmasi perilaku LGBT, akan tetapi putusan tersebut menunjukkan bahwa MK pada prinsipnya tidak memiliki kewenangan untuk membentuk norma baru atau bertindak selaku Positive Legislator.

Terlepas dari berbagai silang pendapat tersebut, isu perilaku LGBT sampai dengan saat ini masih saja menjadi trending topic di tengah-tengah masyarakat. Teranyar, hasil pemetaan sekaligus pendataan Komisi Penanggulangan AIDS (KPA) Kota Sukabumi sepanjang 2018 menyatakan bahwa masih terdapat ribuan gay atau lelaki seks lelaki (LSL) (liputan6.com). Lebih lanjut di Padang, sebanyak 10 (sepuluh) wanita lesbian diamankan Satuan Polisi Pamong Praja Padang (4/11) dan ternyata diantaranya berperan sebagai 'Butchy' (laki-laki) dalam hubungan asmara mereka (suara.com). lebih lanjut di Bogor, sebagai respon atas maraknya perilaku LGBT, sebanyak 46 organisasi masyarakat melakukan aksi penolakan terhadap perilaku LGBT dan bahkan masyarakat mendesak pemerintah setempat untuk segera menetapkan Peraturan Daerah anti perilaku LGBT (republika.co.id). Melihat perilaku tersebut, masyarakatpun terbelah dalam menuyikapi perilaku LGBT tersebut. Beberapa kelompok masyarakat menganggap bahwa perilaku LGBT selama dilakukan atas dasar suka sama suka bukanlah merupakan perilaku yang bertentangan dengan prinsip prinsip Hak Asasi Manusia yang terdapat dalam konstitusi maupun berbagai peraturan perundang-undangan. Namun sebagian besar masyarakat menganggap perilaku LGBT merupakan perbuatan yang menyimpang dari amanat kosntitusi. Melihat berbagai silang pendapat dan masih maraknya perilaku LGBT, menarik untuk mengurai kembali bagaimana sebenarnya perilaku LGBT dan/atau perkawinan sejenis dari perspektif konstitusi di Indonesia, dan bagaimana pula kaitannya antara perilaku LGBT dan/atau perkawinan sejenis dikaitkan dengan putusan MK Nomor 46/PUU-XIV/2016.

\section{METODE PENELITIAN}

Metode yang digunakan dalam tulisan ini adalah metode penelitian hukum yuridis normatif. Suatu penelitian normatif, haruslah menggunakan pendekatan perundang-undangan (statute Approach), hal ini dikarenakan yang akan diteliti adalah berbagai aturan hukum (Efendi dan Ibrahim, 2018:132). Adapun sifat penelitian yang dipergunakan dalam tulisan ini adalah preskriptif, berpegang pada 
karakteristik ilmu hukum sebagai ilmu terapan, preskripsi yang diberikan di dalam kegiatan penelitian hukum harus dapat dan mungkin untuk diterapkan (Marzuki, 2011:251). Lebih lanjut Peter Mahmud Marzuki (2011:251) menyatakan oleh karena itu yang dihasilkan oleh penelitian hukum, sekalipun bukan asas hukum yang baru atau teori baru, paling tidak argumentasi baru.

\section{Tinjauan Umum mengenai Konstitusi}

Dalam wacana politik, kata konstitusi menurut KC Wheare (1996:1) paling tidak digunakan dalam dua pengertian, Pertama, kata 'konstitusi' digunakan untuk menggambarkan seluruh sistem ketatanegaraan suatu Negara, kumpulan berbagai peraturan yang membentuk dan mengatur atau mengarahkan pemerintahan. Lebih lanjut Wheare (1996:1-2) mengutarakan Peraturan-peraturan ini sebagian bersifat legal, dalam arti bahwa pengadilan hukum mengakui dan menerapkan peraturanperaturan tersebut dan sebagian bersifat non-legal atau ekstra legal, yang berupa kebiasaan, saling pengertian, adat atau konvensi, yang tidak diakui oleh pengadilan sebagai hukum namun tidak kalah efektifnya dalam mengatur ketatanegaraan dibandingkan dengan apa yang secara baku disebut hukum) (KC. Wheare 1996:2). Sedangkan dalam arti sempit, konstitusi dirumuskan K.C. Wheare (1996:3) sebagai berikut:

"Namun, di hampir setiap negara, kecuali Inggris, kata Konstitusi digunakan dalam pengertian yang lebih sempit ketimbang pengertian di atas. Kata ini digunakan untuk menggambarkan bukan seluruh kumpulan peraturan, baik legal maupun non-legal, melainkan kumpulan peraturan yang bisanya dihimpun dalam satu dokumen atau dalam beberapa dokumen yang berkaitan erat. Tidak hanya itu, hasil seleksi ini hampir selalu merupakan seleksi dari peraturan-peraturan hukum semata. Dengan demikian, konstitusi, bagi sebagian besar negara-negara di dunia, merupakan hasil seleksi dari peraturan-peraturan hukum yang mengatur pemerintahan negara tersebut dan telah dihimpun dalam sebuah dokumen).

C.F. Strong sebagaimana dikutip Ni'matul Huda (2008:19) mengemukakan pendapatnya tentang konstitusi bahwa konstitusi adalah suatu kumpulan asas-asas yang menyelenggarakan kekuasaan pemerintahan, hak-hak dari yang diperintah dan hubungan antara pemerintah dan yang diperintah). Secara umum konstitusi atau undang-undang dasar berisi 3 (tiga) hal pokok, yaitu: Pertama, adanya jaminan terhadap hak-hak asasi manusia dan warga negara; Kedua, ditetapkannya susunan ketatanegaraan yang bersifat fundamental; dan Ketiga, adanya pembagian dan pembatasan tugas ketatanegaraan yang juga bersifat fundamental (Soemantri, 1987:45).

Jika dilihat dari teori jenjang, materi muatan konstitusi atau undang-undang dasar sebagai aturan dasar/pokok pada prinsipnya sangat terbatas pada hal-hal pokok dan mendasar sedangkan materi muatan aturan pelaksana bersifat teknis dan sangat terperinci (Al Atok, 2015:17). Menurut A.A.H Struycken, undang-undang dasar sebagai konstitusi tertulis merupakan dokumen formal yang berisi (Soemantri, 1987:2):

1. Hasil perjuangan politik bangsa di waktu lampau;

2. Tingkat-tingkat tertinggi perkembangan ketatanegaraan bangsa;

3. Pandangan tokoh-tokoh bangsa yang hendak diwujudkan, baik waktu sekarang maupun untuk masa yang akan datang;

4. Suatu keinginan, dengan mana perkembangan kehidupan ketatanegaraan bangsa hendak dipimpin.

Miriam Budiardjo (2009:177-178) dalam bukunya "Dasar-Dasar Ilmu Politik", menyatakan bahwa undang-undang dasar memuat ketentuan-ketentuan mengenai :

1. Organisasi negara, misalnya pembagian kekuasaan antara badan legislatif, eksekutif dan yudikatif serta hubungan di antara ketiganya. Undang-undang dasar juga memuat bentuk negara (misalnya federal atau negara kesatuan), beserta pembagian kekuasaan antara pemerintah federal dan pemerintah negara bagian antara pemerintah dan pemerintah daerah. Selain itu undangundang dasar memuat prosedur untuk menyelesaikan masalah pelanggaran yurisdiksi oleh salah satu badan negara atau pemerintah dan sebagainya. Dalam arti ini undang-undang dasar mempunyai kedudukan sebagai dokumen legal yang khusus;

2. Hak-hak asasi manusia;

3. Prosedur mengubah undang-undang dasar (amandemen);

4. Adakalanya memuat larangan untuk mengbah sifat tertentu dari undang-undang dasar. Hal ini biasanya ada jika para penyusun undang-undang dasar ingin menghindari terulangnya kembali hal-hal yang baru saja diatasi, seperti misalnya munculnya seorang diktator atau kembalinya suatu monarki. Misalnya,Undang-Undang Dasar Federasi Jerman melarang untuk mengubah sifat federalisme karena dikhawatirkan bahwa sifat unitarisme dapat melicinkan jalan untuk munculnya kembali seorang diktator seperti hitler; 
5. Merupakan suatu aturan hukum yang tertinggi yang mengikat semua warga negara dan lembaga negara tanpa kecuali.

Dalam sejarahnya di dunia barat, konstitusi dimaksudkan untuk menentukan batas wewenang penguasa, menjamin hak rakyat dan mengatur jalannya pemerintahan. Sedangkan di dalam negara-negara yang mendasarkan dirinya atas demokrasi konstitsional, undang-undang dasar mempunyai fungsi yang khas, yaitu membatasi kekuasaan pemerintah sedemikian rupa, sehingga penyelenggaraan kekuasaan tidak bersifat sewenang-wenang (Thaib, 2013:18-19). Oleh karena itu, setiap konstitusi senatiasa mempunyai 2 (dua) tujuan yaitu (Soetoprawiro, 1987:31):

1. Untuk memberikan pembatasan dan pengawasan terhadap kekuasaan politik; dan

2. Untuk membebaskan kekuasaan dari kontrol mutlak para penguasa, serta menetapkan bagi para penguasa tersebut batas-batas kekuasaan mereka.

Menurut Komisi Konstitusi Majelis Permusyawaratan Rakyat Republik Indonesia, kedudukan dan fungsi konstitusi adalah sebagai berikut (Sinaga, 2005:17-19):

1. Konstitusi berfungsi sebagai dokumen nasional (national document) yang mengandung perjanjian luhur, berisi kesepakatan-kesepakatan tentang politik, hukum, pendidikan, kebudayaan, ekonomi, kesejahteraan dan aspek fundamental yang menjadi tujuan negara;

2. Konstitusi sebagai piagam kelahiran baru (a birth certificate of new state). Hal ini merupakan bukti adanya pengakuan masyarakat internasional, termasuk untuk menjadi anggota Perserikatan Bangsa-Bangsa, karena itu sikap kepatuhan suatu negara terhadap hukum internasional ditandai dengan adanya ratifikasi terhadap perjanjian internasional;

3. Konstitusi sebagai sumber hukum tertinggi. Konstitusi mengatur maksud dan tujuan terbentuknya suatu negara dengan sistem administrasinya dan adanya kepastian hukum yang terkandung dalam pasal-pasalnya, unifikasi hukum nasional, social control, memberikan legitimasi atas berdirinya lembaga-lembaga negara termasuk pengaturan tentang pembagian dan pemisahan kekuasaan antara organ legislatif, eksekutif dan yudisial. Konstitusi sebagai sumber hukum tidak saja berfungsi sebagai a tool of social engineering dan social control, melainkan harus juga mampu merespon secara kritis perkembangan zaman;

4. Konstitusi sebagai identitas nasional dan lambang persatuan. Konstitusi menjadi suatu sarana untuk memperlihatkan berbagai nilai dan norma suatu bangsa dan negara, misalnya simbol demokrasi, keadilan, kemerdekaan, negara hukum, yang dijadikan sandaran untuk mencapai kemajuan dan keberhasilan tujuan negara. Konstitusi suatu negara diharapkan dapat menyatakan persepsi masyarakat dan pemerintah, sehingga memperlihatkan adanya nilai identitas kebangsaan, persatuan dan kesatuan, perasaan bangga dan kehormatan sebagai bangsa yang bermartabat. Konstitusi dapat memberikan pemenuhan atas harapan-harapan sosial, ekonomi dan kepentingan politik. Konstitusi tidak saja mengatur pembagian dan pemisahan kekuasaan dalam lembaga-lembaga politik seperti legislatif, eksekutif dan yudisial, akan tetapi juga mengatur tentang penciptaan keseimbangan hubungan (checks and balances) antara aparat pemerintah di pusat maupun di daerah;

5. Konstitusi sebagai alat untuk membatasi kekuasaan. Konstitusi dapat berfungsi untuk membatasi kekuasaan, mengendalikan perkembangan dan situasi politik yang selalu berubah, serta berupaya untuk menghindarkan adanya penyalahgunaan kekuasaan. Berdasarkan alasan tersebut, menjadi sangat penting diperhatikan seberapa jauh serta berupaya untuk menghindarkan adanya penyalahgunaan kekuasaan. Berdasarkan alasan tersebut, menjadi sangat penting diperhatikan seberapa jauh formulasi pasal-pasal dalam konstitusi mengakomodasi materi muatan pokok dan penting sehingga dapat mencegah timbulnya penafsiran yang beranekaragam;

6. Konstitusi sebagai pelindung Hak Asasi Manusia dan kebebasan warga negara. Konstitusi memberikan perlindungan terhadap hak-hak asasi manusia dan hak-hak kebebasan warga negara. Hal ini merupakan pengejawantahan suatu negara hukum cengan ciri-ciri equality before the law, non-diskriminatif dan keadilan hukum (legal justice) dan keadilan moralitas (social and morality justice).

Bagir Manan sebagaimana dikutip Sihombing (2017:220) menyatakan indonesia sebagai negara hukum yang menganut ajaran negara berkonstitusi sebagaimana layaknya negara-negara modern lain, memiliki konstitusi tertulis yang disebut Undang-Undang Dasar 1945. Lebih lanjut Bagir Manan menyatakan bahwa Undang-Undang Dasar 1945 ini ditempatkan sebagai fundamental law sehingga menjadi hukum dasar atau sumber pembuatan hukum-hukum yang lainnya dan sebagai higher law Undang-Undang Dasar 1945 merupakan hukum tertinggi dalam tata urutan Perundang-undangan Republik Indonesia (Sihombing, 2107:221). sebagai konsekuensi Undang-Undang Dasar Negara 
Republik Indonesia tahun 1945 (UUDNRI Tahun 1945) ditempatkan sebagai hukum dasar, maka berbagai peraturan perundang-undangan yang ada di Indonesia harus selalu bersumber dan berpedoman dari hukum dasar tersebut. Pengabaian terhadap hal tersebut mengakibatkan suatu peraturan perundangundangan tidak memiliki legitimasi secara yuridis.

\section{PEMBAHASAN dan HASIL}

\section{Perilaku LGBT dalam perspektif Konstitusi}

Dilihat dari segi filosofis, seluruh sistem hukum Indonesia tidak dapat dilepaskan dari pandangan yang menyatakan bahwa Pancasila sebagai filosofische grondslag dimana Pancasila harus dilihat sebagai cita hukum yang merupakan bintang pemandu (Wangsa dan Kristian,2015:69). Menurut Rudolf Stammler sebagaimana dikutip Wangsa dan Kristian (2015:69), bahwa cita hukum (rechtsidee atau the idea of law) berperan sebagai bintang pemadu (leitstren). Layaknya bintang dengan terangnya, cita hukum harus mampu mengarahkan hukum agar mampu mencapai cita-cita masyarakat (Wangsa dan Kristian,2015:69).

Berdasarkan ketentuan Pasal 2 beserta penjelasan Undang-Undang Nomor 12 Tahun 2011 tentang Pembentukan Peraturan Perundang-undangan disebutkan bahwa Pancasila merupakan sumber dari segala sumber hukum. Penempatan Pancasila sebagai sumber dari segala sumber hukum Negara sejalan dengan yang dinyatakan Hans Nawiasky, bahwa isi staatsfundamentalnorm (norma fundamental negara) ialah norma yang merupakan dasar bagi pembentukan konstitusi atau undang-undang dasar dari suatu negara (Staatsverfassung), termasuk norma pengubahannya.

Hakikat hukum suatu Staats-fundamentalnorm ialah syarat bagi berlakunya suatu konstitusi atau undang-undang dasar (Farida, 2010:41). Dalam konteks Indonesia, maka Pancasila sebagai norma fundamental negara menjadi dasar keberlakuan Undang-Undang Dasar Negara Republik Indonesia Tahun 1945 (UUDNRI Tahun 1945).

Dalam pembukaan UUDNRI Tahun 1945 mengandung pesan moral, dimana terdapat pengakuan dan peranan Tuhan Yang Maha Esa dalam meraih kemerdekaan Indonesia. Lebih lanjut pada alinea keempat UUDNRI Tahun 1945 dinyatakan bahwa, “... disusunlah Kemerdekaan Kebangsaan Indonesia itu dalam suatu Undang-Undang Dasar Negara Republik Indonesia, yang terbentuk dalam suatu susunan Negara Republik Indonesia yang berkedaulatan rakyat dengan berdasar kepada Ketuhanan Yang Maha Esa, dan selanjutnya diderivasi kembali dalam Pasal 29 ayat (1) yang berbunyi "Negara berdasar atas Ketuhanan Y.M.E".

Sebagai aturan dasar Negara atau higher law, maka UUDNRI Tahun 1945 jelas menekankan moral Ketuhanan menjadi fondasi dari setiap pembentukan hukum di Indonesia (Sirait, 2017:630). Cerminan moral dan nilai Ketuhanan dapat dilihat pada setiap pembentukan/penetapan peraturan perundang-undangan di Indonesia, dimana pada bagian pembukaan setiap jenis peraturan perundangundangan wajib mencantumkan frasa "DENGAN RAHMAT TUHAN YANG MAHA ESA"(Sihombing,2016:3) . Hal ini sejalan dengan amanah ketentuan butir 15 Lampiran II UndangUndang Nomor 12 Tahun 2011 tentang Pembentukan peraturan perundang-undangan yang berbunyi: "Pada pembukaan tiap jenis Peraturan Perundang-undangan sebelum nama jabatan pembentuk Peraturan Perundang-undangan dicantumkan Frasa Dengan Rahmat Tuhan yang Maha Esa yang ditulis seluruhnya dengan huruf kapital yang diletakkan di tengah marjin.

Lebih lanjut Maria Farida (2010:49) mengungkapkan bahwa aturan dasar Negara/aturan pokok Negara ini merupakan landasan bagi pembentukan peraturan perundang-undangan baik undang-undang (formell gesetz), maupun peraturan perundang undangan lain yang lebih rendah. Lebih lajut Hamid Attamimi, sebagaimana dikutip Maria Farida (2010:49) menyatakan bahwa :

"isi penting bagi aturan dasar selain garis-garis besar atau pokok-pokok kebijaksanaan Negara juga terutama aturan-aturan untuk memberlakukan dan memberikan kekuatan mengikat kepada norma-norma hukum peraturan perundang-undangan, atau dengan perkataan lain menggariskan tata cara membentuk peraturan perundang-undangan yang mengikat umum.”

Dengan demikian UUDNRI Tahun 1945 dijadikan sebagai landasan moral dan yuridis bagi setiap warga Negara dalam bertingkah laku termasuk dalam hal pelaksanaan hak untuk membentuk keluarga dalam rangka melanjutkan keturunan yang diwujudkan dalam norma peraturan perundangundangan. Apabila ditelisik melalui pendekatan empirik terkait dengan perumusan substansi norma dalam UUDNRI Tahun 1945 khususnya mengenai hak berkeluarga dan melanjutkan keturunan didapati bahwa (MKRI, 2010:56):

"Masyarakat Indonesia yang berkembang sejak masih sangat sederhana sampai modern, pada prinsipnya merupakan masyarakat kekeluargaan. Masyarakat kekeluargaan telah mengenal pranata sosial yang menyangkut hak dan kewajiban masyarakat yang terdiri atas pranata religius 
yang mengakui bahwa manusia adalah ciptaan Tuhan Yang Maha Esa dengan segala hak dan kewajibannya; pranata keluarga sebagai wadah manusia hidup bersama untuk mengembangkan keturunan dalam menjaga kelangsungan keberadaannya;..."

Hal tersebut diatas pula yang mendasari kelahiran ketentuan Pasal 28 B ayat (1) UUDNRI tahun 1945 yang berbunyi : "Setiap orang berhak membentuk keluarga dan melanjutkan keturunan melalui perkawinan yang sah". Ketentuan Pasal 28 B ayat (1) tersebut mengandung makna bahwa perkawinan yang sah merupakan prasyarat untuk adanya hak untuk membentuk keluarga dan mendapatkan keturunan tanpa terikat dalam perkawinan yang sah (Asshiddiqie,2009:115). Lebih lanjut ketentuan Pasal $28 \mathrm{~J}$ ayat (2) UUDNRI Tahun 1945 menyatakan :

"Dalam menjalankan hak dan kebebasannya, setiap orang wajib tunduk kepada pembatasan yang ditetapkan dengan undang-undang dengan maksud semata-mata untuk menjamin pengakuan serta penghormatan atas hak dan kebebasan orang lain dan untuk memenuhi tuntutan yang adil sesuai dengan pertimbangan moral, nilai-nilai agama, keamanan dan ketertiban umum dalam suatu masyarakat demokratis".

Konstruksi perkawinan yang terdapat dalam UUDNRI Tahun 1945 bertujuan untuk membentuk suatu keluarga dan melanjutkan keturunan yang tunduk terhadap pembatasan yang ditetapkan dalam peraturan perundang-undangan. Dalam berbagai peraturan Perundang-undangan di bidang Perkawinan terdapat batasan yang sangat jelas bahwa hanya mengakui perkawinan antara laki-laki dan perempuan (Sihombing, 2016:4). Sehingga perilaku LGBT atau pelampiasan hasrat seksual melalui perkawinan sesama jenis tidak mendapatkan ruang dalam konstitusi kita. Selain itu perkawinan antar sesama jenis tidak mampu melanjutkan keturunan, perilaku perkawinan sejenis ini dapat mendekontruksi pemaknaaanpemaknaan lembaga perkawinan sebagai suatu tempat legal untuk memuaskan hasrat seksualitasnya tanpa memandang keluarga sebagai terbentuknya basis moral hukum (Fuad,2015:126). Bentuk-bentuk perkawinan juga sudah sepatutnya sesuai dengan norma yang bersumber dari nilai yang terdapat dalam konstitusi sehingga tercipta ketertiban di masyarakat (Sirait, 2017:630).

\section{Perilaku LGBT pasca Putusan MK Nomor 46/PUU-XIV/2016}

Sebagaimana telah diuraikan terdahulu bahwa permasalahan perilaku LGBT di Indonesia banyak menimbulkan pertentangan pendapat, antara pihak pro dan kontra. Mereka yang pro terhadap LGBT menyatakan, bahwa negara dan masyarakat harus mengkampanyekan prinsip non-diskriminasi antara lelaki, perempuan, transgender, pecinta lawan jenis (heteroseksual), maupun pecinta sesama jenis (homoseksual). Pendukung LGBT menggunakan pemenuhan hak asasi manusia sebagai dasar tuntutan mereka dengan menyatakan bahwa orientasi seksual adalah hak asasi manusia bagi mereka. Sebaliknya, pihak-pihak yang kontra terhadap LGBT, menilai bahwa LGBT sebagai bentuk penyimpangan dan tidak masuk dalam konsep hak asasi manusia (Santoso, 2016: 221).

Pro dan kontra terkait dengan perilaku LGBT menjadi lebih meluas, setelah adanya Putusan Mahkamah Konstitusi Nomor 46/PUU-XIV/2016 mengenai Pengujian Undang-Undang Nomor 1 Tahun 1946 tentang Peraturan Hukum Pidana atau Kitab Undang-Undang Hukum Pidana juncto UndangUndang Nomor 73 Tahun 1958 tentang Menyatakan berlakunya Undang-Undang Nomor 1 Tahun 1946 tentang Peraturan Hukum Pidana atau Kitab Undang-Undang Hukum Pidana. Pihak yang pro terhadap LGBT menafsirkan bahwa Putusan tersebut cenderung melegalkan LGBT, sedangkan pihak lain menafsirkan bahwa Putusan tersebut menyatakan bahwa Mahkamah Konstitusi tidak memiliki wewenang untuk membuat tindak pidana baru (Imanuel, 2017).

Secara resmi melalui Juru Bicara Mahkamah Konstitusi, Fajar Laksono menyampaikan bahwa 5 (lima) hakim berpendapat bahwa substansi permohonan dimaksud sudah menyangkut perumusan delik atau tindak pidana baru yang mengubah secara mendasar baik subjek yang dapat dipidana, perbuatan yang dapat dipidana, sifat melawan hukum perbuatan tersebut, maupun sanksi/ancaman pidananya (Imanuel, 2017). Adapun substansi permohonan sebagaimana termuat dalam petitum pemohon pada initnya adalah meminta mahkamah untuk memperluas cakupan atau ruang lingkup dan mengubah jenisjenis perbuatan yang dapat dipidana dalam pasal-pasal KUHP yang yang dimohonkan pengujian karena sudah tidak sesuai lagi dengan perkembangan masyarakat, sementara jika menunggu proses legislasi yang sedang berlangsung saat ini tidak dapat dipastikan kapan akan berakhir. Dengan kata lain, pemohon meminta kepada Mahkamah Konstitusi untuk melakukan kebijakan pidana (criminal policy) dalam pengertian merumuskan perbuatan yang sebelumnya bukan merupakan perbuatan yang dipidana menjadi perbuatan pidana (delict), yaitu (lihat Putusan MK No.46/PUU-XIV/2016):

a. Zina, sebagaimana diatur dalam Pasal 284 KUHP, akan menjadi mencakup seluruh perbuatan persetubuhan antara laki-laki dan perempuan yang tidak terikat dalam suatu ikatan perkawinan yang sah; 
b. Pemerkosaan, sebagaimana diatur dalam Pasal 285 KUHP, akan menjadi mencakup semua kekerasan atau ancaman kekerasan untuk bersetubuh baik yang dilakukan oleh laki-laki terhadap perempuan maupun yang dilakukan oleh perempuan terhadap laki-laki;

c. Perbuatan cabul, sebagaimana diatur dalam Pasal 292 KUHP, akan menjadi mencakup setiap perbuatan cabul oleh setiap orang dengan orang yang berjenis kelamin yang sama, bukan hanya terhadap anak dibawah umur.

Berdasarkan petitum yang diajukan pemohon, Mahkamah dalam pertimbangannya
menguraikan bahwa:

“....berkenaan dengan kebijakan pidana atau politik hukum pidana, hal itu adalah sepenuhnya berada dalam wilayah kewenangan pembentuk undang-undang. berbeda dengan bidang hukum lainnya. Hukum pidana dengan sanksinya yang keras yang dapat mencakup perampasan kemerdekaan seseorang, bahkan nyawa seseorang, maka legitimasi Negara untuk merumuskan perbuatan yang dilarang dan diancam pidana serta jenis sanksi yang diancamkan terhadap perbuatan itu dikontruksikan harus dating dari persetujuan rakyat, yang dalam hal ini mewujud pada organ Negara pembentuk undang-undang (Dewan Perwakilan Rakyat bersama Presiden yang keduanya dipilih langsung oleh rakyat)...”

Pendapat 5 (lima) orang hakim tersebut dilihat oleh masyarakat umum dari perdebatan zina dan LGBT merupakan sebuah ironi. Sehingga masyarakat umum menilai bahwa Mahkamah Konstitusi mendukung zina dan LGBT. Bahkan secara ekstrem mereka menyatakan bahwa 5 (lima) orang hakim yang menolak perkara tersebut pro zina dan LGBT (Hermawan, 2017).

Padahal dalam putusan tersebut secara eksplisit Mahkamah Konstitusi menegaskan tidak menolak gagasan pembaharuan terhadap Kitab Undang-Undang Hukum Pidana, namun Mahkamah Konstitusi berpendapat bahwa hal itu sepenuhnya merupakan open legal policy pembentukan undangundang. Terkait dengan hal tersebut, 4 (orang) hakim dissenter menyatakan bahwa pada hakikatnya Mahkamah Konstitusi tidak memperluas ruang lingkup zina dan perilaku LGBT, melainkan sekedar mengembalikan apa yang telah dipersempit oleh pemerintah kolonial Hindia Belanda melalui Wetboek van Strafrecht selama ratusan tahun (Febriansyah, 2017).

Akan tetapi, pendapat dari 5 (lima) orang hakim konstitusi yang menolak perumusan delik atau tindak pidana baru karena dianggap mengambil kewenangan legislatif dalam membentuk undang-undang sebagai positive legislature seyogianya sudah tidak berdasar. Karena sebelum perkara ini diputuskan sudah ada putusan-putusan Mahkamah Konstitusi yang memberikan norma baru, seperti dekriminalisasi pasal penghinaan Presiden, mengubah kualifikasi delik penghinaan kepada pejabat dari delik biasa menjadi delik aduan, soal makna permufakatan jahat, konstitusionalitas sifat melawan hukum dalam undang-undang tindak pidana korupsi dan sebagainya (Febriansyah, 2017).

Pergeseran peran Mahkamah Konstitusi dari negative legislature menjadi positive legislature dikarenakan praktik dan kebutuhan lapangan menghendaki demikian. Di mana menurut Ronald Dworkin, Mahkamah Konstitusi telah menerapkan judicial discreation. Dengan judicial discreation, positive legislature bukan kemudian berarti Mahkamah Konstitusi memiliki kewenangan legislator sebagaimana lembaga legislatif membuat undang-undang. Mahkamah Konstitusi tetaplah lembaga peradilan dengan kewenangan mengadili, dan memutus perkara. Untuk itu, karena judicial discreation itu pula, Mahkamah Konstitusi itu menemukan hukum, bukan membuat hukum (Martitah, 2013: 175).

Hal ini juga sejalan dengan yang dikatakan oleh mantan Hakim Mahkamah Konstitusi, Laica Marzuki, bahwa "biarkan Mahkamah Konstitusi membuat putusan yang bersifat mengatur, sebagai inovasi atau pembaharuan sesuai dengan rasa keadilan yang ada dalam masyarakat. Inilah yang disebut “judicial activism” (Martitah, 2013: 179).

Selain itu, dalam menjalankan kewenangannya, Mahkamah Konstitusi tidak boleh hanya bersandarkan pada semangat legalitas formal peraturan-peraturan tertulis, melainkan harus mampu menggali dan menghadirkan nilai keadilan substantif bagi masyarakat pencari keadilan. Semangat menegakkan nilai-nilai keadilan substantial tersebut dijawab Mahkamah Konstitusi dengan putusanputusan yang tidak terpasung oleh keterbatasan rumusan normatif undang-undang (Mahfud, 2009: 11). Sejalan dengan hal tersebut, Satjipto Rahardjo (2010:169) mengungkapkan bahwa perlu ada keberanian melakukan rule breaking dan keluar dari rutinitas penerapan hukum, out of the box lawyering. Penegakan hukum tidak berhenti pada menjalankan hukum secara apa adanya, melainkan menjadi tindakan yang kreatif (Rahardjo, 2010:169).

Pendapat 4 (empat) orang hakim dissenter yang menyatakan bahwa Negara Indonesia merupakan "Negara Hukum yang berdasar atas Ketuhanan Yang Maha Esa yang senantiasa menjamin kemerdekaan tiap-tiap penduduk untuk memeluk agamanya masing-masing dan untuk beribadat menurut 
agamanya, serta mengakui dan menghormati kesatuan-kesatuan masyarakat hukum adat beserta hak-hak tradisionalnya sepanjang masih hidup dan sesuai dengan perkembangan masyarakat dan prinsip NKRI yang diatur dalam Undang-Undang. Konsepsi ini menegaskan bahwa peraturan perundang-undangan di Indonesia harus senantiasa sejalan dan sama sekali tidak boleh bertentangan dengan dasar Ketuhanan Yang Maha Esa dan nilai agama serta living law yang sesuai dengan perkembangan masyarakat dan prinsip NKRI. Sehingga perilaku LGBT tentunya bertentangan dengan nilai agama dan living law yang ada dalam masyarakat Indonesia.

Terkait dengan alasan hak asasi manusia yang diajukan sebagai alasan untuk menerima perilaku LGBT juga tentunya tidak relevan diajukan di Indonesia. Karena dalam pelaksanaannya, hak asasi manusia berdasarkan ketentuan Pasal 28J ayat (2) Undang-Undang Dasar Negara Republik Indonesia bahwa dalam menjalankan hak dan kebebasannya, setiap orang wajib tunduk kepada pembatasan yang ditetapkan dengan undang-undang dengan maksud semata-mata untuk menjamin pengakuan serta penghormatan atas hak dan kebebasan orang lain dan untuk memenuhi tuntutan yang adil sesuai dengan pertimbangan moral, nilai-nilai agama, keamanan, dan ketertiban umum dalam suatu masyarakat yang demokratis.

Bahkan dalam putusan Mahkamah Konstitusi Nomor 2-3/PUU-V/2007, Mahkamah Konstitusi menyatakan bahwa berdasarkan original intent dan penafsiran sistematis hak asasi manusia yang diatur mulai dari Pasal 28A sampai dengan 28I Undang-Undang Dasar Negara Republik Indonesia Tahun 1945 tunduk terhadap pembatasan yang diatur dalam Pasal 28J ayat (2) Undang-Undang Dasar Negara Republik Indonesia Tahun 1945. Untuk hak asasi manusia yang tidak bertentangan dengan nilai-nilai agama saja masih bisa dibatasi pelaksanaannya apalagi yang bertentangan dengan nilai-nilai agama tentunya tidak diakui sebagai hak asasi manusia.

Pada prinsipnya pasca putusan Mahkamah Konstitusi Nomor 46/PUU-XIV/2016, bukan sebagai dasar dalam melegalkan perilaku LGBT dan/atau perkawinan sejenis di Indonesia. Putusan ini hanya menyatakan bahwa kewenangan untuk memberikan norma baru sesuai dengan pendapat mayoritas hakim Mahkamah Konstitusi adalah open legal policy dari pembentuk undang-undang. Diakui atau tidaknya perilaku LGBT dan/atau perkawinan sejenis di Indonesia sudah menjadi tanggung jawab dan kewenangan dari pembentuk undang-undang dalam hal ini Presiden dan Dewan Perwakilan Rakyat.

\section{KESIMPULAN}

Berdasarkan uraian terdahulu dapat disimpulkan bahwa :

1. Konstruksi perkawinan yang terdapat dalam UUDNRI Tahun 1945 bertujuan untuk membentuk suatu keluarga dan melanjutkan keturunan yang tunduk terhadap pembatasan yang ditetapkan dalam peraturan perundang-undangan, sehingga perilaku LGBT dan/atau perkawinan sejenis tidak mendapatkan ruang dalam konstitusi atau UUDNRI Tahun 1945, Meskipun, UUDNRI Tahun 1945 tidak memberikan ruang terhadap perilaku LGBT dan/atau perkawinan sejenis bukan berarti mengabaikan hak-hak asasi kaum LGBT sebagai warga negara yang diakui dalam konstitusi maupun peraturan perundang-undangan lainnya.

2. Pada prinsipnya putusan Mahkamah Konstitusi Nomor 46/PUU-XIV/2016, bukan sebagai dasar dalam melegalkan perilaku LGBT dan/atau perkawinan sejenis di Indonesia. Putusan ini hanya menyatakan bahwa kewenangan untuk memberikan norma baru sesuai dengan pendapat mayoritas hakim Mahkamah Konstitusi adalah open legal policy dari pembentuk undang-undang. Diakui atau tidaknya perilaku LGBT dan/atau perkawinan sejenis di Indonesia sudah menjadi tanggung jawab dan kewenangan dari pembentuk undang-undang dalam hal ini Presiden dan Dewan Perwakilan Rakyat. Dengan demikian perlu didorong agar pembentuk undang-undang segera melakukan percepatan pembaharuan hukum pidana di Indonesia, untuk menghindari kekosongan hukum terkait dengan perilaku LGBT dan/atau perkawinan sejenis.

\section{DAFTAR PUSTAKA}

Dahlan Thaib, dkk, 2013, Teori dan Hukum Konstitusi, Jakarta : Rajawali Pers

Fokky Fuad, 2015, Filsafat Hukum, Akar Religiousitas Hukum, Jakarta, Prenadamedia Group

Jimly Asshiddiqie, 2009, Komentar Atas Undang-Undang Dasar Negara Republik Indonesia, Jakarta : Sinar Grafika

Joenaidi Efendi dan Johnny Ibrahim, 2018, Metode Penelitian Hukum (Normatif dan Empiris), Jakarta : Prenada Media.

Mahfud MD, 2009, Konstitusi dan Hukum dalam Perdebatan Isu, Jakarta: Rajawali Pers.

Maria Farida, 2010 Ilmu Perundang-Undangan: Jenis, Fungsi dan Materi Muatan, Yogyakarta, Kanisius. Martitah, 2013, Mahkamah Konstitusi; Dari Negative Legislature ke Positive Legislature?, Jakarta: Konstitusi Press. 
Miriam Budiardjo, 2009, Dasar-Dasar Ilmu Politik, Jakarta : Gramedia Pustaka Utama,

Ni'matul Huda, 2008, UUD 1945 dan Gagasan Amandemen Ulang, Jakarta : Rajawali Press.

Nyana Wangsa dan Kristian, 2015, Heurmenetika Pancasila, Orisinalitas dan Bahasa Hukum Indonesia, Bandung, Refika aditama

Peter Mahmud Marzuki, 2011, Penelitian Hukum, Jakarta: Prenadamedia Group

Rosyid Al Atok, 2005, Konsep Pembentukan Peraturan Perundang-undangan; Teori, Sejarah dan Perbandingan dengan Beberapa Negara Bikameral, Malang : Setara Press

Satjipto Rahardjo, 2010, Penegakan Hukum Progresif, Jakarta : Kompas Media Nusantara.

Sri Soemantri, 1987, Prosedur dan Sistem Perubahan Konstitusi, Bandung : Alumni

Wheare, KC, 1996, Konstitusi-Konstitusi Modern (Modern Constitution), Bandung : Nusa Media.

Mahkamah Konstitusi Republik Indonesia, 2010, Naskah Komprehensif Perubahan Undang-Undang Dasar Negara Republik Indonesia Tahun 1945, Buku VIII, Jakarta : Kepaniteraan MKRI.

Artikel, Jurnal dan Website :

Eka NAM Sihombing, "Masa Depan Legalisasi Perkawinan Sejenis", Jurnal Hukum Perancang Peraturan Perundang-Undangan, Volume 2, Nomor 1-Mei 2016

Ilham Hermawan, "Zina, LGBT, dan Putusan MK”, detiknews.com, diakses 13 Oktober 2018.

Johan Imanuel, "Alternatif Pengaturan Pidana LGBT dalam KUHP”, detiknews.com diakses 13 Oktober 2018.

Meilanny Budiarti Santoso, "LGBT dalam Perspektif Hak Asasi Manusia”, Social Work Jurnal, Volume 6, Nomor 2 - Desember 2016.

Reza Fikri Febriansyah, "Soal Zina \& "Mahkota" MK", hukumonline.com, diakses 13 Oktober 2018

Timbo Mangaranap Sirait, Menilik Akseptabilitas Perkawinan Sesama Jenis di dalam Konstitusi Indonesia, Jurnal Konstitusi, Volume 14, Nomor 3, September 2017 